\section{Under the Rainbow: Migration, Precarity and People Power in Post-Apartheid South Africa}

Critical Sociology $1-18$

(C) The Author(s) 2016

Reprints and permissions: sagepub.co.uk/journalsPermissions.nav DOI: I0.1 I77/08969205I562III8 crs.sagepub.com

@SAGE

\author{
Carl-Ulrik Schierup \\ REMESO, Linköping University, Sweden
}

\begin{abstract}
The article focuses on systemic drivers of poverty, inequality and precarious livelihoods. It discusses the transformation of South Africa's labour force management and its migratory system from a centralized management of unfree labour by the apartheid state bureaucracy, to a post-apartheid state of precarity, driven by 'flexploitation'. The nexus of precarious work and a fracturing citizenship is seen to represent a duality of flexibility linking practices of employment and labour control to areas like welfare benefits, citizenship status, political participation and informal livelihoods. This is applicable to migrants and natives alike, but with migrants being particularly flexible. The author connects the issue of precarity with politics of xenophobia seen as a stratagem for the retaining of hegemony confronting looming labour struggles and an insurgent citizenship of the poor. The argument revolves around precarity as representing a rallying point for resistance as well as a social condition.
\end{abstract}

\title{
Keywords
}

sociology, political economy, precarity, migration, social inequality, social movements, racism, South Africa

\section{Ubuntu Shattered?}

At the end of the 1980s the long struggle against apartheid in South Africa, led by the African National Congress (ANC), headed towards victory. Supported by an alliance with the South African Communist Party (SACP) and the Congress of South African Trade Unions (COSATU), the ANC entered in the early 1990s negotiations with the former enemy and political pillar of apartheid, the Afrikaner-led National Party. This resulted in the formal termination of apartheid in 1994, free democratic elections and the rise of a new ANC-led government. The South Africa born out of this 'National Democratic Revolution' was to be transformed into an inclusive 'Rainbow Nation'; a metaphor coined by Nobel Prize Winner Archbishop Desmond Tutu to designate the new multicultural community of a 'Rainbow 
People of God' in a state earlier defined by apartheid's deep rift between white and black. It was a dream of a non-racial South African 'exceptionalism' embodied in the Ubuntu philosophy that speaks of 'the very essence of being human' (Tutu, 1999: 31). It cherishes the qualities of forgiveness and appeasement guiding the celebrated South African Truth and Reconciliation Commission which were supposed to close the long era of apartheid's race-class oppression and internecine violence. However, for leftist political forces in the movement against apartheid, the establishment of liberal democracy and the formal equality of citizens stood for a still 'unfinished revolution' (Alexander, 2010). From this perspective Ubuntu means more than a humanitarian gospel. As enshrined in the Congress of the People-driven Freedom Charter from 1955, it enveloped the wider vision of a sustained activist counter-society that would contest a predacious capitalism and build people power on the basis of unbounded organization. It included promises to harness South Africa's natural wealth to create dignified livelihoods for all, through nationalization of the mines and redressing centuries of white land grabbing by redistributing the land 'to those who work it'.

Dreams apart, the Rainbow Nation, in actuality, was to become a rocky edifice designed by 'architects of poverty', contends political economist Moeletsi Mbeki (2009). Riches and power for today's elites emanate, as before, from South Africa's gargantuan underground resources of metals and minerals. Yet there is no 'pot of gold' under the Rainbow's end, but a toxic trap of a predatory extractionism that continues to drive poverty and precarity of work and citizenship in a still deeply racialized society. There is in substance 'no black in the rainbow' argues human rights fellow Reshoketswe Mapokgole (2014), in another critical exposé which depicts a multifaceted so-called 'xenophobia' as 'Afrophobia' or 'Negrophobia'; pitting poor black 'natives' against poor black 'aliens' in a society where inequality remains oceans deep and where a hyper-exploitative migration regime continues to be one of the most controversial issues.

Against the background of these and other outspoken voices in debates over a current crisis of economy, politics and society, we tap in this essay into a rich fund of critical research on South Africa. Without pretentions to review an extended polemic of often mutually conflicting positions on the post-apartheid transformation, the objective is to merge perspectives on populist politics and migrant labour in a transmuting political economy with a dialectic take on the precarity of work and citizenship.

The essay starts with a condensed review of the post-apartheid transition focusing on systemic drivers of poverty, inequality and precarious livelihoods. We discuss the transformation of South Africa's labour force management and its migratory system from a centralized regiment of unfree labour ${ }^{1}$ by the apartheid state bureaucracy, to a post-apartheid state of precarity, driven by 'flexploitation' (Bourdieu, 1999: 84). We stress (with Goldring and Landholt, 2011) the complex intertwining of precarious work and a fracturing citizenship in the political economy of migration; a synthetic merger of two trends in contemporary globalization. It represents a 'duality of flexibility' (Lazaridis and Psimmenos, 2000) linking practices of employment and labour control to areas like welfare benefits, citizenship status, political participation and informal livelihoods, applicable to migrants and natives alike, but with migrants being particularly 'flexible'. We go on to look at politics of xenophobia as a stratagem for the retaining of hegemony at a moment marked by fierce labour struggles and an insurgent citizenship of the poor, beyond the reach of neoliberal governance. Our argument revolves accordingly around 'precarity' as representing 'both a condition and a possible rallying point for resistance' (Waite, 2008: 412).

\section{Making a Post-Apartheid Precariat}

Apartheid framed a racial labour and migration regime distinguished by an 'extreme extraeconomic coercion of the majority of the workforce' (Legassick, 1974: 255). It represented a new 
exceptionally austere phase in the accumulation strategy of capitalism in South Africa, in the dispossession of black Africans of their land and in the making and remaking of a system of migrancy designed for the hyper-exploitation of cheap unfree labour. An already since long-established colonial system for 'turning indigenous people into unfree wage labourers' (Terreblanche, 2003: 9ff) had been remoulded, further extended and institutionally embedded under British colonial rule at the start of gold mining in the late 19th century (First, 1982; Johnson, 2007). It was a migrant labour regime covering large parts of Southern Africa. After the end of the South African War and the establishment of the Union of South Africa as a British dominion in 1910, the Afrikaner elite, with proven skills in state administration and the effective procurement of cheap black unfree labour, became a strategic ally of white Anglo-capitalists who controlled the mining industry. It was at the time favoured over a potential alliance with a black professional and business elite with their roots in 19th-century British colonialism (Mbeki, 2009). 'Native Reserves' - instituted through the Land Act of 1913 and based on an alliance between Anglo-controlled mining companies and Afrikaner landowners - meant a further step in colonialism's alienation of black Africans from the land. Apartheid, formally instituted in 1948, remoulded and further consolidated this historical process of alienation. It turned former 'natives' into 'foreigners'; by the logic of so-called 'separate development' contained in shrunken 'homelands', so-called 'bantustans'. It barred black Africans from holding citizenship in the 'white' Republic of South Africa, and - through a centralized statemonitored labour regime powered by administrative and securitization measures - it caged millions of alienized 'foreign natives' (Neocosmos, 2006) in a permanent condition of rural-urban migrancy and unfree labour.

The decade preceding the final caving in of apartheid in the early1990s was marked by recession, international sanctions and widening cracks in the white hegemony. An exclusion of black Africans from qualified professions had become increasingly inopportune for influential factions of capital, and a powerful anti-apartheid social movement - in particular, the growing strength of a 'community unionism' breaching workplaces and black townships, city and rural areas, with migrant workers on the forefront (Bramble, 2003) - had turned apartheid's strategy for procuring cheap labour down a cul-de-sac.

The Convention for a Democratic South Africa (CODESA), negotiated between the ANC and the National Party in the early 1990s, brought an end to apartheid, manifested through the first universal multiparty elections in 1994. It established a non-racial political democracy and universal citizenship and avoided a protracted civil war, but it came at the price of selling out on values of social equality and policies of redistribution that had been pivotal for the trade unions, the SACP and left factions of the ANC. It pertained moreover to the ditching of demands for nationalization of the mines and land reform to benefit the rural poor. It speeded up a development that had already taken off under the crisis-ridden apartheid of the 1980s; a transformation from a state-regulated regime, characteristic of Africa's post-colonial developmental state, to a neoliberal one (Buhlungu, 2010). In 1996 it was inscribed in a neoliberal structural adjustment programme, the Growth, Employment, and Redistribution programme (GEAR), implicating the dismantling of national currency regulations, the adoption of free trade agreements, tax reduction, corporate restructuring detrimental to labour rights and the organization of workers, welfare state retrenchment and the privatization of public services. While COSATU initially won the battle to embed social democratic labour market institutions in economic governance, it lost the battle to pursue corresponding fiscal and monetary policies (Fine, 2014: 336). The tripartite alliance's original neo-Keynesian Reconstruction and Development Programme (RDP), spearheaded by COSATU, was put on the backburner together with the vision of a social democratic post-apartheid social compact with its priority on employment growth and an inclusive redistributive policy for combating poverty and social inequality (Maharajh, 2011; Barchiesi, 2011). 
One strand of South African critical research focuses on elite transition and shifting race-class alliances driving this development (e.g. Bond, 2000). The transition reflects, argues Mbeki (2009: 39-100), the persistent post-apartheid power and influence of the South African Minerals-Energy Complex (MEC). It was, argues Terreblanche (2003: 95-6) in his monumental work on the history of inequality in South Africa, headed by the powerful Anglo-American Corporation in a 'fourth phase' of the search for an advantageous accumulation strategy at the point when apartheid's centralized bureaucratic state and its vast security apparatus had - under the impact of unionization and the anti-apartheid struggle - played out its role in procuring cheap labour for the mining industry. MEC 'oligarchs' now intensified a search for a new alliance with the modern liberal black urban South African middle class with its roots in British colonialism, which had historically been a driving force within the ANC. The lynchpin of this alliance was to become Black Economic Empowerment (BEE). It meant a transfer of corporate shares to a limited number of selected black so-called Previously Disadvantaged Individuals (PDIs), including prominent union leaders, with the manifest aim of supporting the making of a prospering black bourgeoisie. Its effects were supposed eventually to 'trickle down' and alleviate poverty among the black majority. An initial step in its realization was the setting up of the Black Economic Empowerment Commission (BEEC) in 1998, chaired by Cyril Ramaphosa; in the 1980s a prominent trade union leader credited with the building up of one of South Africa's most important labour unions, the National Union of Mineworkers; today Deputy President of the ANC and the country, and one of South Africa's wealthiest and most powerful individuals. ${ }^{2}$

Through their alliance with an emerging black political and economic elite, the MEC oligarchy could retain their grip on the huge natural resources of South Africa, while at the same time, aided by the provisions of the neoliberal compact, safeguard their capital against political perturbations through transferring corporate headquarters and profits abroad, thus being licensed to disinvest their apartheid-era wealth (Bond, 2013: 575). The deal provided a radical opening for the importation of manufactured consumer goods. It lowered the cost of labour for the MEC, but resulted in overwhelming international competition with the domestic non-MEC manufacturing sector, a shedding of permanent jobs and the creation of new precarious jobs mainly located in retailing and services (Mbeki, 2009; Newman and Takala-Greenish, 2014; Barchiesi, 2011). It was to produce a multi-million post-apartheid South African precariat caught between a toxic web of agencies forging temporary, contingent and insecure employment and the commodification of 'de-racialized' policies for combating poverty and inequality.

Growing welfare transfers and policies of service delivery and procurement of housing to poor South Africans during the $2000 \mathrm{~s}^{3}$ may, seen from this perspective, have served to secure survivalist livelihoods, to boost the hegemony of the ANC and to safeguard its victory in consecutive general elections. It has kept the poor waiting for an imagined more prolific 'trickle down' of the wealth of the nation, which will, however, hardly materialize under the conditions of the prevailing political economy. It has only marginally faced up to the 'triple challenge' of poverty, inequality and unemployment, still marring the nation (OXFAM, 2013).

According to World Bank statistics ${ }^{4}$ in 2011 over half of all South Africans lived below the national poverty line of around US\$4 a day; more than twice as much as in Mexico, Brazil or Peru. This exceptionally high level of poverty for a middle-income country reflects South Africa's apparent inability to reduce inequality. Measured by a Gini coefficient close to 0.70 , South Africa has one of the highest rates of inequality in the world, outdoing the United States (Gini 41), Brazil (53) or Russia (40 in 2009) - three of the globe's most unequal societies. Inequality in incomes is not limited to wages and wealth, but also encompasses the means of obtaining access to, and use of, services, public goods and natural resources (OXFAM, 2013). One factor pushing poverty and inequality is unemployment -25 per cent, according to official statistics, but closer to 40 per cent 
if those who have given up applying for formal employment are counted. Unemployment is particularly high among poor blacks, black youth and in former Bantustan areas (Leibbrandt et al., 2009: 12; OECD, 2013). A profound race-class inequality is reproduced through a two-tiered public-private health service and through a school system which fails to favour poor black youth in terms of quality of education, pass rates and employment prospects.

Average interracial income inequality has decreased during the post-apartheid period, but remains massive. In comparison, intra-racial inequality among black South Africans has risen. Black representation among the professional and managerial strata has grown substantially. Increasing numbers have entered the nation's professional and business elites through, among other factors, affirmative action and the BEE, but at the expense of the continued exploitation of a huge reserve army of cheap precarious labour, particularly amongst black women, youths and internal and cross-border migrants (Gentle, 2011). Poverty and unemployment remain concentrated in former Bantustan areas, but increasingly tilt towards peri-urban informal settlements; black 'townships' with conditions similar to 'shanty towns' or 'favelas' in the globe's least favoured states, and with a high inflow of internal as well as African cross-border migrants. Poor people who have been evicted, as their homes have been seized on the frontlines of housing privatization, gentrification or governmental prestige projects, have, time and again, become concentrated in the 'blikkies' (new-build corrugated iron shacks) of depressing so-called 'temporary relocation areas' (Ranslem, 2015).

These trends notwithstanding, a more adequate analysis than that which is mostly offered by critics of South Africa's alleged neoliberal trajectory, contends Habib (2013) in South Africa's Suspended Revolution, should build on a thoughtful understanding of shifting constellations of power energized by progressive democratization. The side-lining of the ANC's leftist partners (COSATU and the SACP) within the tripartite alliance in the 1990s must be seen against the background of the global neoliberal political surge of the time, an overwhelming power of corporate capital at the moment of the republic's initial democratic transformation, along with the National Party's continued grip on the army and police. Made possible through democratization, the balance of power has changed during the 2000s with a strengthened clout of COSATU and the SACP and the empowerment of a differentiated and critical post-apartheid civil society. It has meant a progressive reorientation in social policy and infrastructural development, in particular after the election of a supposedly left-leaning Jacob Zuma as leader of the ANC in 2007 and as President of the republic in 2009 (pushed by COSATU, the SACP and the ANC Youth Alliance). It has brought forth a change from neoliberalism to a factual social democratic neo-Keynesian regime with 'hopes and prospects' for the formation of a new inclusive social compact.

This alternative narrative seems, however, to have missed what has, in the European context, been discussed in terms of social democracy's 'Third Way' neoliberal turn, rationalizing a transformation of northern welfare states through the commodification of social policy, health, public services and infrastructure, with widely polarizing consequences in terms of class and 'race' (Schierup et al., 2014). A similar politics of 'commercialisation by stealth' (McDonald and Ruiters, 2012: 170) has been applied by the IMF and the World Bank to transform the developmental state in the global South. A comparable trajectory in South Africa has been analysed by critics in terms of 'Zuma's Own Goal' (Maharaj et al., 2011) that is losing the Rainbow Nation's 'war on poverty' through devising a 'talk left, speak right' commodifying policy agenda embedded in an austere fiscal policy (Bond, 2014).

The argument relates to a policy of providing 'Free Basic Services', guaranteeing a minimum of water and electricity to poor households; yet jeopardized through its marriage to a neoliberal doctrine of 'cost recovery', by allowing service providers to demand exorbitant prices for everything over that minimum, a subcontracting of public service delivery to private corporations or 
NGOs and the establishment of austere systems of prepayment for basic necessities. It runs in tandem with 'Corporate Welfare'. This means providing discounted electricity to industrial users, the MEC in particular, while 'citizens cannot get a dependable supply at any price' (Bond, 2006; also Bond, 2012a); it amounts to the public policy promotion of an 'electric capitalism' with adverse consequences for health, gender equity, environmental sustainability and socio-economic justice (McDonald, 2012). 'Microcredits' is another instrument supposedly combating poverty. However, this operates through distorting microcredit rules and mechanisms administered by the large South African banks and, according to several in-depth studies, functions as another medium for 'accumulation through dispossession', ${ }^{5}$ pushing survivalist strategies over the brink to debt peonage and igniting combustible divisions of race, class and gender in the process (Bateman, 2014; Hietalahti, 2013). It relates, finally, to the embeddedness of amplified state-funded welfare transfers in a dysfunctional wedlock between past dependent paternalistic regulations, reminiscent of the apartheid era, and a disciplinary means testing circumscribed by fiscal rigour. Although deracialized and greatly extended in breadth, this social policy regime is seen as largely 'tokenistic', without the capacity to lift the weight of the world off the backs of South Africa's poor (Bond, 2014). It is a stalemate, argues Barchiesi (2011), which needs to be discussed with a synthesizing focus on the nexus of a disciplinary citizenship and precarious labour.

\section{From Apartheid to 'Flexibility'}

A critical element in South Africa's post-aparteid transformation was the deracialization of labour legislation during the second half of the 1990s, through which apartheid's labour legislation (introduced to protect unionized skilled and semi-skilled white workers) was reformed and extended to cover all unionized, skilled and semi-skilled South African workers. Thus legislation that formerly protected the privileges of an elite of white workers should in future ensure privileges for an elite of post-apartheid workers, of 'whatever race or skin' (Seekings, 2007: 18). But in the same instance it moved, argues Seekings, 'vestiges of the apartheid's era's division between insiders and outsiders inside the workplace [to the] outside of the workplace, so that the (formally) employed were now all insiders whilst the unemployed, casual workers and informally employed remained outsiders'. Here Seekings, following from his work with Nattrass (2005), focuses on one of the drivers of poverty and inequality in post-apartheid South Africa. Yet the argument succumbs to a weakness similar to that of Standing (2011), who sees the 'precariat' as a particular 'class' beyond the insider interests of what remains of Fordism's protected, privileged blue-collar working class and the unions representing them; whereas, following Seymour (2012), 'precarity exerts effects right up the chain of class strata, throughout the working class and into sections of the middle class'. Seeing an enduring opposition between privileged 'insiders' and 'outsiders' without skills and formal employment comes up short when facing a post-apartheid intellectual and political discourse on 'flexibility' that has entered social reality as a 'material force' (Bezuidenhout and Kenny, 2000).

This 'force' poses, as elsewhere (Schierup et al., 2015), an immense challenge to unions. It is manifest in legislation pushing the commodification of labour, but no less through installing a quo ante bellum state of flexibility through informalization, disregarding or covertly circumventing formal regulations. Employment triangulation, 'externalizing work' through outsourcing, sub-contracting and the displacement of responsibility for recruitment, employment, salary and working conditions from large, profit-making corporations to the practices of a multitude of private labour brokers have been identified as drivers of the informalization of labour and the growth of new forms of unfree labour (Benjamin, 2013b, 2013a). Thus, a multitude of opaque corporate practices of 'informalization from above' (Theron, 2010b) has replaced apartheid's top-down extra-economic force as the driver of a casualized, socially insecure and disempowered multitude, bound 
into unfree labour (Benjamin, 2013a). This prescription is established by the repression of organized agency. It is contingent on systemically embedded de-regulation, de-unionization and an ethno-racially rationalized disbanding of broader solidarities.

A composite precarious labour pool is overwhelmingly black, to a considerable degree migrant, and increasingly female. The spaces it occupies become, in turn, sites for active reproduction of 'informalization from below' (Theron, 2010b), where the poor employ inventive livelihood strategies which are beyond the reach of formal regulatory frameworks. A widening grey area has come into existence 'where the boundaries of formal and informal production become hazy and undistinguished ... and where employment is hardly conducive to social inclusion and citizenship' (Barchiesi, 2010: 68). A majority of the employed have been recorded as falling into the precarious category of 'working poor' (Altman, 2006: 11ff). In the wide zone of informality and the vortex of temporary agency work migrants have a 'comparative advantage' for many employers, as they make a particularly cheap and flexible labour force. This pertains to cross-border migrants who are bereft of powers to negotiate due to a dispossessed status (Fine, 2014; Gordon, 2010), above all the undocumented, but is also matched by the 'comparative disadvantage' of domestic migrants, squeezed into unfree labour through forces of unequal regional development, poverty, debt, and their desertion by organized labour (Xulu, 2010).

Migrants from the Bantustans were at the forefront of the struggle against apartheid and yet they remain among South Africa's most disadvantaged and are currently neglected by the unions (Xulu, 2010; Fine, 2014). Abject conditions in former Bantustan areas drive them into poverty-stricken townships. Here they share spaces with a medley of South Africa's most disadvantaged, including a growing population of irregular, trans-border labour migrants and refugees and asylum seekers whose lives in informality are conditioned by an ostensibly liberal, but allegedly corrupt, asylum regime (Amit, 2015). Trans-border migrants travel from neighbouring regions, whence the apartheid regime used to recruit labour, but come also as undocumented labour migrants and as refugees from more distant parts of Africa, such as the Congo and Somalia (Tati, 2008).

Their concrete situation and opportunities depend on the geographical hinterlands they migrate from, the specific dynamics to which they respond, their claims on the South African state, and their respective skills, qualifications and networks (Kok et al., 2006). But as a general trend, the centre of gravity of African cross-border migration has shifted from a preponderance of formally regulated contract labour under apartheid to the employment of undocumented workers in the 2000s (Tati, 2008; Gordon, 2010; Fine, 2014). The adoption of internationally monitored structural adjustment programs across sub-Saharan Africa, often combined with internecine conflicts, has produced increased reliance on informal livelihoods, premised on cross-border migration and petty trading, with South Africa as the prime destination. The prevalent South African response has been to stem migration through a reaffirmation of state sovereignty, exclusionary migration policies and securitization (Evans, 2010: 105; Trimikliniotis et al., 2008); a condition reinforced by new legal restrictions on cross-border migration and the acquisition of citizenship in 2014 (Dube, 2014).

This reflects the ANC's efforts to craft a new national identity after liberation and a politics of confirming citizenship rights for insiders through exclusivism towards neighbours, which consequently incites xenophobia (Fine, 2014; Johnson, 2007). Throughout the post-apartheid period 'illegal migrants' have been vilified by politicians and the media. They are exposed to daily harassment by black 'native' township dwellers. Educating the citizenry in 'migration issues' and encouraging them to "root out" and report "illegal immigrants" to state authorities', together with empowering police officers, has allegedly exacerbated the situation (Neocosmos, 2006: 967). Yet inconsistent institutional practices give rise to permeable borders in spite of restrictions. A 'Fortress South Africa' (Crush, 1999; Trimikliniotis et al., 2008) is similar to 'Fortress Europe' in 'profiting from irregular migration while denouncing it'. ${ }^{6}$ Unlike earlier times, when trans-border 
migrants were concentrated in mining and agriculture, they have now become a preferred labour force in a range of low wage economic sectors, including municipal services, construction, retailing, and health care (Fine, 2014). Police round-ups in informal peri-urban townships and deportations reign, in tandem, with entry through the clandestine practices of private transporters, labour brokers, the police and other public agencies (Kihato and Landau, 2006; Tshabalala, 2015) which are allegedly shot through with corruption (Amit, 2015). Thus the mostly formal and centralized regulation of cross-border African migration under apartheid has been replaced by a predominantly informal regime (Segatti, 2011: 56) according to the logic of which "periods of "tolerance" and "crackdowns" appear to conveniently alternate with periods of labor needs and labor surplus' (cf. Gordon, 2010).

Undocumented migration is neither an entirely new phenomenon nor is it far from being the only route for African labour migrants into South Africa (e.g. Fine, 2014; Vigneswaran, 2007). At the same time migrants need not be 'undocumented' in order to be incorporated in novel types of informalized precarious labour. They may be formally recruited through temporary contracts, they may be refugees or asylum seekers, and yet be entangled in webs of informal labour relations. A range of studies have scrutinized the differential impact of informalization, spurious labour relations and the manipulation of migrant status, race and gender in, among others, capitalist agriculture (Theron, 2010a), municipal services (Barchiesi, 2011; Miraftab, 2004), hospitality (MiWORC, 2014), manufacturing (Barchiesi, 2010) and the building industry (Cottle and Rombaldi, 2014).

Still, it is the precarization of work and livelihoods fuelled by the post-apartheid accumulation strategy of the MEC that could bring the ANC's 'social contract' with South Africa's working poor to breaking point (Cohen, 2013). On 16 August 2012 this was put under the spotlight by the massacre by the South African Police Service of striking mineworkers protesting against the management strategies of the Lonmin mining company bordering the township of Marikana in the Rustenburg platinum belt. It was the horrific climax of a protracted labour conflict, involving - on the one side - the company management, leading cadres of the ANC and the National Union of Mineworkers (one of COSATU's most important affiliates), and - on the other side - the breakaway Association of Mineworkers and Construction Unions (AMCU), mobilizing the protesting workers, including numerous migrant workers.

Beyond corporate reports portraying sustainable labour force management and responsible community development, the Marikana imbroglio exposes an extended illicit undercutting of labour standards (Forrest, 2013), causing frequent work-related accidents, injuries, illnesses and early deaths in the mining industry (Frankel, 2013: 24ff). It is contingent on methodical strategies of 'informalization from above', on inept management of migration (Frankel, 2013: $82 \mathrm{ff}$ ) and a proliferating micro-financial industry's 'deliberate and programmed engagement with some of the most vulnerable and exploited individuals in the country' (Bateman and Sharife, 2014). Migrant workers are recruited to the most arduous jobs from the same impoverished regions across South and Southern Africa whence the apartheid regime drafted migrant labour. They are exposed to illicit practices of labour brokers, traffickers, township landlords and usurers. Many are undocumented and unprotected 'irregulars'. But migrants also increasingly belong to the most vulnerable among the growing numbers of temporary 'contracted workers', who are, contends Frankel (2013: 99), in fear of dismissal 'persuaded' to enter 'hazardous areas where permanent workers will not go ... and do not have to go under existing legislation'. Their factual conditions depend on the 'unscrupulousness of brokers and endusers, the nature of demand in the market, the availability of men, women and children desperate for work under any circumstances, and ... the capacity of the Department of Labour to monitor its own laws and regulations'. 


\section{Xenophobia - A Strange Fruit of Democracy}

Alongside acts of overarching labour solidarity in this new fair world of 'flexibility', ethno-nationally rationalized conflicts loom; in the mining industry as well as in other economic sectors and across townships. This mirrors the refurbished politics of labour force control as well as jeopardized union strategies for the containment of informal labour (Theron, 2010b). Control in the apartheid period was, contend Bezuidenhout and Buhlungu (2011), subject to centralized bureaucratic and police containment whereas today's corporate control is dominated by a fragmenting differentiation driven by 'the market'. It is inscribed in a political economy of re-racialization.

The labour unions have, in general, not been willing or able to include in their ranks a multiethnic precariat of 'natives' and 'foreigners' embroiled in informal conditions of work and vulnerable livelihoods (Barchiesi, 2011; Theron, 2010b; Fine, 2014). COSATU - leaving its community unionism behind after the demise of apartheid - has, according to its critics, failed to address the conditions of precarious workers and poor township dwellers in general and migrants in particular (Fine, 2014; Barchiesi, 2011; Hlatshwayo, 2010; Buhlungu, 2010). It has taken a defensive stance, rather than an active one, on the organization of cross-border migrants in South Africa and across the region. They are the people who, through their 'foreign' backgrounds, the informality of their livelihoods, their precarious position in terms of rights and their exposure to vigilantism and harassment, represent the embodiment of today's South African precariat. They are - which has been documented in several critical studies - seldom seen by unions as social agents to be included on their own premises into a broader struggle for changing the balance of forces in workplaces and townships; and therefore the unions share responsibility for the persistence of a fragmenting xenophobia (Hlatshwayo, 2010; Fine, 2014).

Xenophobia has been a feature of the post-apartheid era since its beginning and remains a persistent daily reality (Crush, 2000; Neocosmos, 2015). It is reflected in a strange discursive transition from 'Kaffir', a pejorative term for black South Africans under apartheid with colonial roots, to KwereKwere; today's principal derogative term for the black African 'foreigner', with a 'peculiar speech', an 'alien culture' and with an imagined darker pigmentation than 'native' black South Africans. Far from shared by all South Africans, so-called 'xenophobic attitudes' have been proved common and equally represented among 'the poor and the rich, the employed and the unemployed, the male and the female, the black and the white, the conservative and the radical' (Crush and Pendleton, 2004: 2). Yet, it is a violent, repeatedly deadly, black-against-black harassment and looting of migrants across poor black townships which has come to embody the image of a virulent 'sickness of xenophobia' (Neocosmos, 2015).

This poor-against-poor violence has been projected as the consequence of persistent race-class inequality (Bond et al., 2010). Others have, with reference to Frantz Fanon and Steve Biko, depicted today's 'xenophobia' as 'apartheid vertigo' (Matsinhe, 2011); a ghost from the past representing a perverted black 'self-hate' (Mbembe, 2015). The urgency of 'exorcising the demons within' (Landau, 2011: 2) is, however, about more than the state of a black post-colonial psyche. It concerns 'cracks in the contemporary legal order and social compact' with roots in the history of 'South African statecraft' . This is manifested, argue Misago, Landau and Monson (2009), in practices of the post-apartheid bureaucracy in the form of labelling, marginalizing and separating populations, with 'non-nationals' as the 'functional equivalent' of black South Africans under the old regime. It is reproduced through and exacerbated by a micropolitical clientelism in local communities that may turn these divides between 'aliens' and 'natives' into 'resources', through violence and looting.

Gordon (2010), for one, advances a synthetic explanatory framework of law, political economy and struggles over privileges of citizenship embedded in the prevailing post-apartheid hegemony. 
The 'division between citizen and foreigner' is, he argues, stipulated through legal discrimination, echoed in common sense political discourse, the media and in popular lore shared across the nation. Yet this all functions not simply to highlight cultural or genetic 'difference', but to 'create the particularly intensive vulnerability that leaves migrants open to forms of violence and exploitation' (Gordon, 2010: 7). In order to perform this function 'such migrants must be exempt from constitutional norms that were designed to protect individual liberties'. It is a condition forged trough a "“state of exception" seen as a state's right to its own self defence'. Xenophobia emerges in this account as a precondition and tool of a legal-political regime's engineering of a 'xenoracialized' multitude of 'new black' ' alien working poor, evidenced by the daily harassment of migrants in black townships, and increasingly the inner-city ghettos of Pretoria, Johannesburg, and Durban. They become victimized as struggles over realizing citizenship, social and economic rights, benefits and access to public services promised by the transition to democracy grow callous across townships exposed to un- and under-employment, informalization of livelihoods, commodification of public services, and the debt-trap of a microcredit industry destroying 'thin reserves of intra- and inter-ethnic community trust, mutuality, reciprocity and solidarity' (Bateman, 2014: 94). Thus apartheid's racist system 'maximising cheap labour with little financial burden on the state', contends Desai and Walsh (2010: 12), has been supplanted by 'a cheap labour pool without rights within a cheap labour pool of black South Africans'. They are the alienized 'members of society without recourse to the state ... policed through violence both by the state and by other poor South Africans who see themselves as bearers (and possible beneficiaries) of certain rights and concessions'.

A multitude of marginalized actors, sharing lack of protection, extreme vulnerability and dependence on opaque institutional arrangements, may appear a fertile ground for the proliferation of a society with the 'psychology of violence' operating 'on the basis of the weakest link' (Mingxitama, 2008: 196). But discriminatory politics engineering precarity for flexploitation can 'lead to all sorts of different reactions from self-immolation to class struggle' (Neocosmos, 2015). In spite of the apartheid state's determined efforts to engineer ethno-racial divisions, labour migrants from the wider southern African region have been mobilized in the anti-apartheid struggle alongside de-nationalized 'foreign natives' (Neocosmos, 2006).

Is this not the conundrum at the centre of the xenophobic puzzle from where one should embark on a complex analysis?, asks Neocosmos (2006). It is a perspective from which xenophobia of today emerges as the strange fruit of the 'National Democratic Revolution'. It encapsulates a discrepancy between a broadly mobilizing pan-African discourse and inclusive activist idea of citizenship during the struggle against apartheid, with a community-anchored trade unionism as vanguard, and an exclusive xenophobic conception of citizenship marking the post-apartheid ideology of nation-building. Here, in the name of human rights and settling the bill of historical injustices, the ghost from the past is represented, not as xenophobia, but as migration, in the Rainbow Nation's narrative of nation-building associated, per se, with apartheid's malign system of forced labour.

\section{Whither the 'Unfinished Revolution'?}

Unceasing xenophobic violence has brought the contradictions of a deepening political and social crisis into the open and lent momentum to critiques of disjunctions between dream and reality. The embrace of neoliberalism has 'stolen the South African Dream', bewails Satgar (2011). The past two decades of the republic's integration into global circuits of accumulation has, he contends, brought an end to any substance in the positive post-apartheid discourse of a 'South African exceptionalism'. South Africa has become one of many 'laboratories' of a discriminatory 'neoliberalism 
with African characteristics' (Satgar, 2012); an 'ugly world of ... capitalist barbarism' marred by 'racist and xenophobic dog-eat-dog conflicts', mourns Alexander (2010) in 'South Africa: An Unfinished Revolution?'. Yet South Africa remains 'exceptional' in the wider regional and African context; that is to say in its role as a sub-imperial hegemon inherited from the apartheid state, albeit dressed in new clothes (Bond, 2012b; Samson, 2009). The republic figures as a regional force in the 21st-century's new 'Scramble for Africa' with demands for 'regime change' as strings attached to the politics of investment and loans. It is a 'Fortress South Africa' that has refurbished a system of migrancy and unfree labour with colonial origins across the Southern African region and subSaharan Africa (Evans, 2010). It is at the same time a society where xenophobic imaginations represent the embodiment of an idea of exceptionalism, depicting 'South Africans as superior to the rest of the continent ... [and] fellow human beings who exhibit differences from the supposed norm as outsiders to community and therefore as enemies of the nation who can then become legitimate targets for violence' (Neocosmos, 2015).

Marikana's bloody Thursday- labelled 'democracy's Sharpeville' (Frankel, 2013: 4ff) - can be seen as a 'turning point' (CASAC, 2012). It exposed the need for South Africa's political and social crisis to be understood against the background of a crisis of neoliberal globalization in general and of the post-apartheid accumulation strategy in particular, with a continued dominance of the minerals-energy complex (Mohamed, 2007). From this perspective we may understand Marikana as the crucible from which arose a new increasingly violent phase in the search for a viable accumulation strategy with no accord, so far, in sight. But twisting the optic, we may as well, in a Polanyian mood (Polanyi, 1957 [1944]), discern a crisis of the neoliberal accumulation strategy riding in tandem with a multifarious popular 'countermovement' which contests the accumulation-throughdispossession that has shattered the dream of and struggle for social justice, welfare and dignity invested in the National Democratic Revolution. It appears, read through Gramsci, to herald a moment of crisis where the still not old post-apartheid hegemony may be dying but where what is yet to be born remains obscured.

For the labour movement the neoliberal trajectory meant 'a paradox of victory' (Buhlungu, 2010). As labour unions are bled through their complicity in corporate restructuring and elite transition - and as a promised dawn of dignified work and inclusive citizenship is clouded by poverty, precarious labour and debt peonage - large swaths of union members, including many migrant workers stuck in the most arduous jobs for a pittance, have been radicalized by the events at Marikana. A subsequent storm of labour unrest across the country resulted in a deep split in the labour movement which eventually manifested itself through the dramatic splintering of COSATU, the political consequences of which remain indefinite (Bell, 2015).

In the meantime the informal precariat persists on the margins of a labour movement which has sold out its celebrated 'community unionism', once rooted among the township's poor. 'Insurgent citizenship' (Miraftab, 2009) erupted as a new political subject with We Are the Poors (Desai, 2002). It is manifested as daily micro-political resistance, with thousands of protests against housing privatization, forced evictions and the commodification of basic needs like electricity or water. In contrast to 'invited spaces' for 'stakeholder deliberation' between civil society, business and the state, the poor create their own 'invented spaces' as sites for protest and unsolicited community action (Miraftab, 2009). This informal movement of the South African precariat - on the margins of substantial social rights and beyond state control - deserves, intimates Neocosmos (2011), ${ }^{8}$ the honourable designation of an 'uncivil society'. That is one seen to stand out from a 'civil society' of CSOs and NGOs, streamlined by conforming to a legalistic and depoliticizing human rights agenda, and bounded through incorporation in neoliberal governance as service providers or as 'think tanks' financed by the state or international donors. It is a movement of the dispossessed seconded by a rebellious student movement re-claiming 
'people's power' through contesting the political elite's alleged subservience to the nation's colonial heritage and the class and race based disadvantages that continue to permeate the postapartheid educational system (Naicker, 2015).

No matter whether we subscribe to Guy Standing's (2011) controversial designation of the precariat as a new dangerous class, we may agree to the proposition that it is indeed dangerous. But 'dangerous' in representing a floating and yet genuinely political 'uncivil society', situated on the borders of informality and beyond the reach of a governance seen to co-opt, discipline and depoliticize an authorized 'civil society' (Neocosmos, 2011). Thus the creative 'informalization from below' by the poor carries with it more than a flexible and affirmative adjustment to a corporate 'informalization from above'; a transmutation from facilitator of 'flexploitation' to a 'politics of informal people' (Bayat, 1997) resisting 'the tyranny of the market' (Bourdieu, 1999).

A composite South African 'uncivil society' harbours, beyond volatile and localized day-to-day service delivery protests, a range of articulate social movements; among them is the Unemployed People's Movement (UPM), which has taken inspiration from Martin Luther King's dream of building a coast-to-coast poor people's alliance, and the Landless People's Movement - member of the international Via Campesina movement. Faced with the current historical moment's 'farce of economic apartheid', replacing the 'tragedy of apartheid', a new social movement of the poor needs to develop, declares the chairman of the UPM, Ayanda Kota (2012). It will require complex and long-term counter-hegemonic strategies from the ground up for the revolutionary transformation of the 'whole society', the 'participation of the people', and the 'sharing of political power and control over resources'. Such strategies must, explains Kota (2014), merge everyday informal confidence with a 'second task' of creating a wider oppositional subjectivity. This will eventuate only through the improvement of livelihoods (e.g. starting community bakeries, crèches and urban gardens) linked with 'infusing political and social consciousness and building a mass movement', potentially in alliance with a rejuvenated labour movement.

A multifarious low-scale insurgence may at times hold a xenophobic component but often embodies civic organization in solidarity with African non-citizens, highlighting commonality beyond origin or nationality, and thus contesting politics of xenophobia (EAC, 2008; Payn, 2015). South Africa's defiant multitude counts also vibrant organizations and a critical movement born out of African diaspora communities, raising their voices against a xenophobia seen to penetrate institutions at 'both the basis and the top of the state' (e.g. ADF, 2015), in defence of precarious livelihoods and for an inclusive non-racial South Africa. These voices of a defiant South African migritude (Willén, 2015) are, however, too often marginalized, contend Desai and Walsh (2010), in favour of civil recommendations to the state by polished reports funded by international human rights organizations; the same state that -while officially denouncing it - plays with fire through both fanning and exploiting xenophobic violence.

As South Africa's deep social divisions are heading towards breaking point and a widening gulf of mistrust has opened between the ANC leadership and its constituencies, 'xenophobia' enters as a crucial stratagem of a still hegemonic power block in an ongoing political contest. Like elsewhere - not least across changing political landscapes of an 'integral Europe' (Holmes, 2000) -politics of xenophobia has become an ideopolitical bedfellow of 'fast capitalism'. Marking out boundaries of belonging operates a populist stratagem of governance for containing the social crisis, reasons Hart (2013): to co-opt, redirect, pacify and politically exploit a multifarious, but still diffuse, poor people's upheaval. This articulates the general problem for South Africa of elite transition in a post-colonial community, as raised by Fanon (1967). It embeds, paradoxically, the reproduction of the deep structures of apartheid.

Yet, the ruling tripartite coalition is ridden with internal conflict; and out of its cracks - as from conflicts splitting a formerly unitary labour movement - emanate new detached counter-hegemonic 
political projects profiling themselves as leftist alternatives with the 'Freedom Charter' and 'people power' as signifiers. ${ }^{9}$ At this junction of social and political crisis, the fortunate days of the particular class-race alliance on which the post-apartheid South African hegemony was first founded may be counted; but it begs the question whether 'hopes and prospects' for the formation of a new social compact could be carried forward from within the original tripartite political coalition, promising a 'more radical phase' of the National Democratic Revolution to come (Umsebenzi, 2015), or alternatively - by forces of contestation challenging it from beyond. In any event precarious labour, poor people's movements, migration and xenophobia are crucial stratagems of the moment. It relates to the need for building inclusive alliances with movements of a precariat of 'natives' and 'aliens' in a society where a politics of xenophobia and a twisted nationalist narrative, reading migration as the spectre of South Africa's apartheid past, has become a smoke-screen covering up the 'suspended revolution' of its present.

\section{Acknowledgements}

I am grateful for comments and suggestions from David Johnson, The Open University, Aline Mugisho, African Diaspora Forum and the Willy Brandt School of Public Policy, Raúl Delgado Wise, University of Zacatecas, David Fasenfest, Editor of Critical Sociology, Martin Bak Jørgensen, Ålborg University, Xolani Tschabalala, Aleksandra Ålund and other colleagues at REMESO, Linköping University.

\section{Funding}

I appreciate the generous funding by FORTE, the Swedish Research Council for Health, Working Life and Welfare [grant number 2006-1524] and through a Swedish Research Links grant from the Swedish Research Council [grant number 2013-6682].

\section{Notes}

1. 'Unfree' in terms of workers being incapacitated to freely negotiate contracts for selling their labour (following Fudge and Strauss, 2013).

2. Formal BEE legislation was passed in 2003 and later consecutively amended.

3. For details see The Republic of South Africa (2013).

4. Source: World Bank Poverty and Inequality Statistics, April 2015.

5. Referring to Harvey (2005).

6. Tobias (2012: 6), quoting Guilfoyle (2010: 1).

7. Alluding to Sivanandan (2001).

8. Relating to Chatterjee's (2002) 'politics of the governed' and recirculating Bayat's (1997) term for the 'politics of informal people'.

9. Notably the Economic Freedom Fighters (EFF) and the United Front (UF), which represents a coalition of left-leaning forces with its spine in unions that have ceased toeing the line with COSATU.

\section{References}

ADF (2015) Open letter to President Jacob Zuma. African Diaspora Forum. Available (consulted 15 November 2015) at: http://adf.org.za/?q=node/57

Alexander N (2010) South Africa: An unfinished revolution? The fourth Strini Moodley Annual Memorial Lecture, held at the University of KwaZulu-Natal on 13 May 2010. Marxists Internet Archive. Available (consulted 15 November 2015) at: https://www.marxists.org/archive/alexander/2010-unfinished-revolution.pdf

Altman M (2006) Low wage work in South Africa. Paper presented to: IZA/World Bank Conference on Employment \& Development IZA, Berlin, 25-27 May 2006. Available (consulted 15 November 2015) at: http://www.iza.org/conference_files/worldb2006/altman.pdf 
Amit R (2015) Queue Here for Corruption: Measuring Irregularities in South Africa's Asylum System. Pretoria and Johannesburg: Lawyers for Human Rights and African Centre for Migration and Society.

Barchiesi F (2010) Informality and casualization as challenges to South Africa's industrial unionism: Manufacturing workers in the East Rand/Ekurhuleni Region in the 1990s. African Studies Quarterly 11(2-3): 67-85.

Barchiesi F (2011) Precarious Liberation: Workers, the State and Contested Social Citizenship in Postapartheid South Africa. New York and Durban: SUNY Press and the University of KwaZulu-Natal Press.

Bateman M (2014) South Africa's post-apartheid microcredit-driven calamity. Law, Democracy and Development 18.

Bateman M and Sharife K (2014) The destructive role of microcredit in post-apartheid South Africa. In: Bateman M and Maclean K (eds) Seduced and Betrayed: Exposing the Contemporary Microfinance Phenomenon. Santa Fe, NM: SAR Press.

Bayat A (1997) Un-civil society: The politics of the 'informal people'. Third World Quarterly 18(1): 53-72.

Bell T (2015) SACP's flag is palest pink. GroundUP. Available (consulted 15 November 2015) at: http:// groundup.org.za/article/sacps-flag-palest-pink_3156

Benjamin P (2013a) The persistence of unfree labour: The rise of temporary employment agencies in South Africa and Namibia. In: Fudge J and Strauss K (eds) Temporary Work, Agencies, and Unfree Labour: Insecurity in the New World of Work. London \& New York, NY: Routledge: 118-143.

Benjamin P (2013b) Law and Practice of Private Employment Agency Work in South Africa. Geneva: ILO.

Bezuidenhout A and Buhlungu S (2011) From compounded to fragmented labour: Mineworkers and the demise of compounds in South Africa. Antipode 43(2): 237-263.

Bezuidenhout A and Kenny B (2000) The language of flexibility and the flexibility of language: Postapartheid South African labour market debates. SWOP. Johannesburg: University of the Witwatersrand. Available (consulted 15 November 2015) at: http://www.wits.ac.za/academic/humanities/swop/publications/17591/

Bond P (2000) Elite Transition: From Apartheid to Neoliberalism in South Africa. London and Ann Arbor, MI: Pluto Press

Bond P (2006) South Africa embraces corporate welfare: Mega deal subsidies over services for the poor. Multinational Monitor 27(5). Available (consulted 15 November 2015) at: http://www.multinationalmonitor.org/mm2006/092006/bond.html

Bond P (2012a) In South Africa, the poor pay the electricity bill of the world's largest mining company. ejolt. Available (consulted 15 November 2015) at: http://www.ejolt.org/2012/10/in-south-africa-the-poorpay-the-electricity-bill-of-the-worlds-largest-mining-company/

Bond P (2012b) Subimperialism as lubricant of neoliberalism: South Africa's emergence from the apartheid laager. Panel on 'Resistance and Civil Society' at the Centre for Global Political Economy, University of Sussex, 16 May. Available (consulted 15 November 2015) at: http://www.southgov.net/attachments/ article/212/Bond\%20Sussex\%2016\%20May\%202012\%20draft.pdf

Bond P (2013) Debt, uneven development and capitalist crisis in South Africa: From Moody's macroeconomic monitoring to Marikana's microfinance mashonisas. Third World Quarterly 34(4): 569-592.

Bond P (2014) 'Talk left, walk right' in South African social policy: Tokenistic extension of state welfare versus bottom-up commoning of services. UKZN. Available (consulted 15 November 2015) at: http:// sds.ukzn.ac.za/files/2014-02-19\%20Bond\%20SA\%20social\%20policy.pdf

Bond P, Ngwane T and Amisi B (2010) Xenophobia and Civil Society: Why Did It Happen? Durban: University of KwaZulu-Natal Centre for Civil Society.

Bourdieu P (1999) Acts of Resistance: Against the Tyranny of the Market. New York: The New Press.

Bramble T (2003) Social movement unionism since the fall of apartheid: The case of NUMSA on the East Rand. In: Bramble T and Barchiesi F (eds) Rethinking the Labour Movement in the 'New South Africa'. Aldershot: Ashgate, 187-204.

Buhlungu S (2010) A Paradox of Victory: COSATU and the Democratic Transformation in South Africa. Scottsville: University of KwaZulu-Natal Press. 
CASAC (2012) Statement by the Council for the Advancement of the South African Constitution, on the impact of Marikana on South Africa's constitutional order. Polity org.za. Available (consulted 15 November 2015) at: http://www.polity.org.za/article/sa-statement-by-the-council-for-the-advancementof-the-south-african-constitution-on-the-impact-of-marikana-on-south-africas-constitutional-order$-03102012-2012-10-03$

Chatterjee P (2002) The Politics of the Governed. New York: Columbia University Press.

Cohen R (2013) The Marikana tragedy: South Africa's social contract with its working poor breaks down. Inroads. Available (consulted 15 November 2015) at: http://inroadsjournal.ca/the-marikana-tragedy/

Cottle E and Rombaldi M (2014) Lessons from South Africa's FIFA World Cup: Brazil and Its Legacy for Labour. Johannesburg: University of the Witwatersrand (The Global Labour University).

Crush J (1999) Fortress South Africa and the deconstruction of apartheid's migration regime. Geoforum 30(1): $1-11$.

Crush J (2000) The dark side of democracy: Migration, xenophobia and human rights in South Africa. In: Appleyard R (ed.) The Human Rights of Migrants [offprint of International Migration 38(6), Special Issue 3]. Geneva: IOM.

Crush J and Pendleton W (2004) Regionalizing xenophobia? Citizen attitudes to immigration and refugee policy in Southern Africa. Cape Town: SAMP, Creda Communications. Available (consulted 15 November 2015) at: http://www.queensu.ca/samp/sampresources/samppublications/policyseries/Acrobat30.pdf

Desai A (2002) We Are the Poors: Community Struggles in Post-Apartheid South Africa. New York, NY: Monthly Review Press.

Desai A and Walsh S (2010) Knowledge and power in South Africa: Xenophobia and survival in the postapartheid state: In: Choudry A and Kapoor D (eds) Global Perspectives on Social Movements and Knowledge Production: Learning from the Ground Up. New York: Palgrave Macmillan.

Dube P (2014) The 'Undesirable' Immigration Regulations 2014. Cape Town: Centre for Constitutional Rights.

EAC (2008) Evicted South Africans rally in support of immigrants. Grassroots International. Available (consulted 15 November 2015) at: http://www.grassrootsonline.org/news/press-releases/evicted-southafricans-rally-support-immigrants

Evans J (2010) The neoliberal turn in the SADC: Regional integration and disintegration. Nokoko (Fall (1)): 101-129. Available (consulted 15 November 2015) at: http://carleton.ca/africanstudies/wp-content/ uploads/5-Evans-Jessica-2010-The-neoliberal-turn-in-the-SADC-Regional-integration-and-disintegration-Nokoko-1.pdf

Fanon F (1967) Black Skin, White Masks. New York: Grove.

Fine J (2014) Migration and migrant workers in the post-apartheid era. Global Labour Journal, 330-346.

First R (1982) The gold of migrant labour. Review of African Political Economy 9(25): 5-21.

Forrest K (2013) Marikana was not just about migrant labour. Mail \& Guardian, 13 September. Available (consulted 15 November 2015) at: http://mg.co.za/article/2013-09-13-00-marikana-was-not-just-aboutmigrant-labour

Frankel P (2013) Between the Rainbows and the Rain: Marikana, Migration, Mining, and the Crisis of Modern South Africa. Johannesburg: Agency for Social Reconstruction.

Fudge J and Strauss K (2013) Temporary work, agencies and unfree labour: Insecurity in the new world of work. In: Fudge J and Strauss K (eds) Temporary Work, Agencies, and Unfree Labor: Insecurity in the New World of Work. New York: Routledge.

Gentle L (2011) Poverty and social movements. In: Maharaj B, Desai A and Bond P (eds) Zuma's Own Goal: Losing South Africa's 'War on Poverty'. Asmara: Africa World Press, 359-380

Goldring L and Landholt P (2011) Caught in the work-citizenship matrix: The lasting effects of precarious legal status on work for Toronto immigrants. Globalizations 8(3): 325-341.

Gordon S (2010) Migrants in a 'state of exception'. Transcience Journal 1(1): 3-21.

Habib A (2013) South Africa's Suspended Revolution: Hopes and Prospects. Athens, OH: Ohio University Press.

Hart G (2013) Rethinking the South African Crisis: Nationalism, Populism, Hegemony [Geographies of Justice and Social Transformation 20]. Athens, GA: University of Georgia Press. 
Harvey D (2005) A Brief History of Neoliberalism. Oxford: Oxford University Press.

Hietalahti J (2013) Trade-offs, rights and responsibilities in the business of microcredit: A case study from South Africa. Academic dissertation, Helsinki, Helsinki University.

Hlatshwayo M (2010) COSATU's attitudes and policies towards external migrants. In: Buhlungu S and Tshoaedi M (eds) COSATU's Contested Legacy: South African Trade Unions in the Second Decade of Democracy. Cape Town: HSRC Press, 228-258.

Holmes DR (2000) Integral Europe: Fast-Capitalism, Multiculturalism, Neofascism. Princeton, NJ, and Oxford: Princeton University Press.

Johnson D (2007) Migrancy and Thabo Mbeki's African Renaissance. In: Gupka S and Omoniyi T (eds) The Cultures of Economic Migration. Aldershot: Ashgate.

Kihato C and Landau LB (2006) The Uncaptured Urbanite: Migration and State Power in Johannesburg. Johannesburg: University of the Witwatersrand, Forced Migration Studies Programme.

Kok P, Gelderblom D, Oucho J, et al. (eds) (2006) Migration in South and Southern Africa: Dynamics and Determinants. Cape Town: HSRC Press.

Kota A (2012) UPM to feed own struggle. Activate [Rhodes University's Independent Student News Source]. Available (consulted 15 November 2015) at: http://activateonline.co.za/upm-to-feed-own-struggle/

Kota A (2014) Some lessons for South Africa's sectarian middle-class lefties. GroundUp. Available (consulted 15 November 2015) at: http://groundup.org.za/article/some-lessons-south-africas-sectarian-middle-class-lefties_2506

Landau LB (2011) Introducing the demons. In: Landau LB (ed.) Exorcising the Demons within. Xenophobia, Violence and Statecraft in Contemporary South Africa. New York: United Nations University Press.

Lazaridis G and Jordanis P (2000) Migrant flows from Albania to Greece: Economic, social and spatial exclusion. In: Baldwin-Edwards M and Arango J (eds) Immigrants and the Informal Economy in Southern Europe. London: Macmillan.

Legassick M (1974) South Africa: Capital accumulation and violence. Economy and Society 3(3): 253-291.

Leibbrandt M, Woolard I, McEwan H, et al. (2009) Employment and Inequality Outcomes in South Africa. Cape Town: School of Economics, University of Cape Town.

McDonald DA (2012) Electric Capitalism: Recolonising Africa on the Power Grid. London: Earthscan Ltd.

McDonald DA and Ruiters G (2012) Careful what you ask for: State-led alternatives to privatization. In: McDonald DA and Ruiters G (eds) Alternatives to Privatization: Public Options for Essential Services in the Global South. London: Routledge.

Maharaj B, Desai A and Bond P (eds) (2011) Zuma's Own Goal: Losing South Africa's 'War on Poverty'. Asmara: Africa World Press

Maharajh R (2011) Innovating Beyond Racial Capitalism: A Contribution Towards the Analysis of the Political Economy of Post-Apartheid South Africa. Lund: Lund University Press.

Mapokgole RB (2014) There is No Black in The Rainbow (Nation): A Bikoist and Fanonian Approach to Understanding 'Xenophobic' Violence in South Africa. London and Cape Town: Trinity College.

Matsinhe DM (2011) Apartheid Vertigo: The Rise in Discrimination against Africans in South Africa [Interdisciplinary Research Series in Ethnic, Gender and Class Relations]. Farnham: Ashgate.

Mbeki M (2009) Architects of Poverty: Why African Capitalism Needs Changing. Johannesburg: Picador Africa.

Mbembe A (2015) Achille Mbembe writes about xenophobic South Africa. Africa is a Country. Available (consulted 15 November 2015) at: http://africasacountry.com/2015/04/achille-mbembe-writes-aboutxenophobic-south-africa/

Mingxitama A (2008) We are not all like that: Race, class and nation after apartheid. In: Hassim S, Kupe T and Worby E (eds) Go Home or Die Here. Johannesburg: Wits University Press.

Miraftab F (2004) Neoliberalism and casualization of public sector services: The case of waste collection services in Cape Town, South Africa. International Journal of Urban and Regional Research 28(2): 874-892.

Miraftab F (2009) Insurgent planning: Situating radical planning in the global south. Planning Theory 32(8): $32-50$. 
Misago JP, Landau LB and Monson T (2009) Towards Tolerance, Law, and Dignity: Addressing Violence against Foreign Nationals in South Africa. Johannesburg: IOM and the Department for International Development (DFID), University of the Witwatersrand.

MiWORC (2014) Migrancy and Labour in the Hospitality Sector in South Africa. Johannesburg: University of the Witwatersrand (African Centre for Migration and Society).

Mohamed S (2007) Industrial policy for economic development proposals. In: Edigheji O (ed.) Rethinking South Africa's Development Path: Reflections on the ANC's Policy Conference Discussion Documents. Johannesburg: Centre for Policy Studies, 81-85.

Naicker C (2015) South African student protests herald the re-emergence of people's power. Scroll.in. Available (consulted 15 November 2015) at: http://scroll.in/article/764715/south-african-student-protests-herald-the-re-emergence-of-peoples-power

Neocosmos M (2006) From 'Foreign Natives' to 'Native Foreigners': Explaining Xenophobia in PostApartheid South Africa. Dakar: CODESRIA Monograph Series.

Neocosmos M (2011) Transition, human rights and violence: Rethinking a liberal political relationship in the African neo-colony. Interface: a journal for and about social movements 3(2): 359-399.

Neocosmos M (2015) The sickness of xenophobia, and the need for a politics of healing. The Daily Maverick, 2 February. Available (consulted 15 November 2015) at: http://scroll.in/article/764715/south-africanstudent-protests-herald-the-re-emergence-of-peoples-power

Newman S and Takala-Greenish L (2014) African industrialisation: Is global value chain development the answer? Joint South Africa/EU initiative, TIPS and Dialogue Facility Conference: International Conference on Manufacturing-Led Growth for Employment and Equality. Johannesburg, 20-21 May 2014. Available (consulted 15 November 2015) at: http://www.tips.org.za/files/african_industrialisation_gvc_nse_tips_paper_march14_-_newman_and_takala-greenish.pdf

OECD (2013) OECD Economic Surveys: South Africa. Paris: OECD.

OXFAM (2013) Is South Africa Operating in a Safe and Just Space? Oxford: OXFAM.

Payn J (2015) 'Xenophobia', service delivery protest and government failure: The case of Thembelihle. anarkismo.net. Available (consulted 15 November 2015) at: http://www.anarkismo.net/article/28228

Polanyi K (1957 [1944]) The Great Transformation: The Political and Economic Origins of Our Time. Boston, MA: Beacon Press.

Ranslem D (2015) 'Temporary' relocation: Spaces of contradiction in South African law. International Journal of Law in the Built Environment 7(1): 55-71.

Samson M (2009) (Sub)imperial South Africa? Reframing the debate. Review of African Political Economy 36(119): 90-103.

Satgar V (2011) Vishwas Satgar: Reclaiming a vision of hope and a life of dignity: Neoliberal South Africa and the narrowing of democratic space. Keynote address delivered by Vishwas Satgar at a Conference of the Democratic Left. Constitutionally Speaking. Cape Town: Pierre de Vos. Available (consulted 15 November 2015) at: http://constitutionallyspeaking.co.za/vishwas-satgar-reclaiming-a-vision-of-hopeand-a-life-of-dignity-neoliberal-south-africa-and-the-narrowing-of-democratic-space/

Satgar V (2012) Beyond Marikana: The post-apartheid South African State. Africa Spectrum 47(2-3): 33-62.

Schierup CU, Ålund A and Kings L (2014) Reading the Stockholm riots - a moment for social justice? Race \& Class 55(3): 1-21.

Schierup CU, Munck R, L-B Branka, et al. (eds) (2015) Migration, Precarity and Global Governance: Challenges and Opportunities for Labour. Oxford: Oxford University Press.

Seekings J (2007) Poverty and inequality after apartheid: The second After Apartheid Conference, Yale University, New Haven. Available (consulted 15 November 2015) at: http://www.yale-university.org/ macmillan/apartheid/seekingsp2.pdf

Seekings J and Nattrass N (2005) Class, Race, and Inequality in South Africa. New Haven, CT: Yale University Press.

Segatti A (2011) Reforming South African immigration policy in the postapartheid period (1990-2010). In: Segatti A and Landau LB (eds) Contemporary Migration to South Africa: A Regional Development Issue. Washington, DC: The International Bank for Reconstruction and Development/The World Bank. 
Seymour R (2012) We are all precarious. On the concept of the 'precariat' and its misuses. New Left Project. Available (consulted 15 November 2015) at: http://www.newleftproject.org/index.php/site/article_comments/we are_all_precarious_on_the concept_of the precariat_and_its_misuses

Sivanandan A (2001) Poverty is the new black. Race \& Class 43(1): 1-5.

Standing G (2011) The Precariat: The New Dangerous Class. London: Bloomsbury Academic.

Tati G (2008) The immigration issues in the post-apartheid South Africa: Discourses, policies and social repercussions. Géopolitique et populations 3: 423-440.

Terreblanche S (2003) A History of Inequality in South Africa 1652-2002. Durban: University of KwaZuluNatal Press.

The Republic of South Africa (2013) Millennium Development Goals. Country Report 2013. Minister's Report. Pretoria: Statistics South Africa.

Theron J (2010a) Sour grapes. Law, Democracy and Development 14: 1-21. Available (consulted 15 November 2015) at: http://dx.doi.org/10.4314/ldd.v14i1.2

Theron J (2010b) Informalization from above, informalization from below: The options for organization. African Studies Quarterly 11(2-3): 87-105.

Trimikliniotis N, Gordon S and Zondo B (2008) Globalisation and migrant labor in a Rainbow Nation: A fortress South Africa? Third World Quarterly 29(7): 1323-1339.

Tshabalala X (2015) Waiting on the move: The social life of mobility governance across the Beitbridge border. Paper in progress. Norrköping: Linköping University (REMESO).

Tutu D (1999) No Future without Forgiveness. New York: Doubleday.

Umsebenzi (2015) Forward to the ANC NGC! And a second, more radical phase of the NDR. Umsebenzi. Voice of the South African Communist Party. Available (consulted 15 November 2015) at: http://www. sacp.org.za/pubs/umsebenzi2/2015/oct.pdf

Vigneswaran D (2007) Free movement and the movement's forgotten freedoms: South African representation of undocumented migrants. RSC Working Paper No. 41. Oxford: Refugee Studies Centre

Waite L (2008) A place and space for a critical geography of precarity? Geography Compass 3(1): 412-433.

Willén J (2015) The curse of the nation state and history as remedy? Xenophobia and migritude in postapartheid South Africa. Discover Society 17, 1 February. Available (consulted 15 November 2015) at: http://discoversociety.org/2015/02/01/the-curse-of-the-nation-state-and-history-as-remedy-xenophobiaand-migritude-in-post-apartheid-south-africa/

Xulu N (2010) COSATU and internal migrant workers: Old fault lines, new dilemmas. In: Bulungu S and Tshoaedi M (eds) COSATU's Contested Legacy: South African Trade Unions in the Second Decade of Democracy. Cape Town: HSRC Press, 212-227. 